\title{
Changes in the concentration of chloride ions in the Volga water (section of the Zhigulevsky hydroelectric complex)
}

\begin{abstract}
For a quantitative assessment of changes in the concentration of chlorides, an analysis of the data of hydrological and hydrochemical observations obtained on the Volga River in the alignment of the Zhigulevsky hydroelectric complex was carried out. For the period 20012018 the average annual concentration of chlorides was $27 \mathrm{mg} / \mathrm{dm}^{3}$, the highest $-31 \mathrm{mg} / \mathrm{dm}^{3}$, and the lowest $-24 \mathrm{mg} / \mathrm{dm}^{3}$. The chloride content was characterized by seasonal variability. During the winter season, the concentration of chlorides increased. The maximum was observed in April, before the beginning of the spring flood. During the spring flood, the chloride concentration decreased, reaching the lowest values in May at the peak of the spring flood. In the summer, the concentration of chlorides gradually increased, and in the autumn, it decreased. The intra-annual amplitude of the average monthly concentrations of chlorides was $14-42 \mathrm{mg} / \mathrm{dm}^{3}$. Such significant intra-annual changes in chlorides in the outlet section of the Kuibyshev reservoir are due to the interaction of the surface and underground components of the water flow of the Cheboksary and Nizhnekamsk reservoirs. In low-water years, the concentration of chlorides increased, and in high-water years, it decreased.
\end{abstract}

Volume 6 Issue 3 - 2021

\author{
VA Seleznev,' AV Selezneva,' KV Bespalova² \\ 'Samara Federal Research Center of the Russian Academy of \\ Sciences, Institute of Ecology of the Volga Basin of the Russian \\ Academy of Sciences, Russia \\ ${ }^{2}$ Togliatti State University, Russia
}

Correspondence: VA Seleznev, Samara Federal Research Center of the Russian Academy of Sciences, Institute of Ecology of the Volga Basin of the Russian Academy of Sciences, Komzina 10,Togliatti, Russia, Email seleznev53@mail.ru

Received: June 05, 202। | Published: June 28, 202 I

\section{Introduction}

Chloride ions are among the main ions in the chemical composition of natural waters. In surface waters, chlorides are ubiquitous, and their content varies within a wide range from 1 to $1000 \mathrm{mg} / \mathrm{dm}^{3}$, depending on natural and climatic conditions. ${ }^{1}$ The primary sources of chlorides in surface waters are igneous rocks, which include chlorinecontaining minerals (sodalite, chlorapatite, etc.), saline deposits, mainly halite. Significant amounts of chlorides enter water bodies: from the oceans through the atmosphere; as a result of the interaction of atmospheric precipitation with soils, especially saline soils; with volcanic emissions. Part of the chlorides is discharged into water bodies with wastewater from point and diffuses sources of pollution. The introduction of chlorides in wastewater is becoming increasingly important. Chlorides have a high migration capacity, which is explained by their good solubility. They have a weakly expressed ability to sorption on suspended solids, and are not consumed by aquatic organisms. ${ }^{2-4}$

The content of chlorides in water affects the state of aquatic ecosystems, organoleptic properties of water and the human body. The increased content of chlorides impairs the taste of water and makes it unsuitable for drinking water supply, restricts its use for many technical and economic purposes, as well as for irrigation of agricultural land. The maximum permissible concentration (MPC) for water bodies for fishery purposes is $300 \mathrm{mg} / \mathrm{dm}^{3}$, for domestic and drinking water supply $-350 \mathrm{mg} / \mathrm{dm}^{3}$. For irrigation of plants, the concentration of chlorides should be at the level of $50-300 \mathrm{mg} / \mathrm{dm}^{3}$, depending on the type of plant.

In the Volga water, the main attention in the study of chloride content was paid to the assessment of the spatial heterogeneity along the length of the river. ${ }^{5-10}$ The patterns of seasonal variability of chlorides were estimated fragmentarily. ${ }^{11}$ Therefore, the purpose of the study is to provide a quantitative assessment of the seasonal variability of chlorides based on the data of systematic long-term observations obtained on the river Volga in the alignment of the Zhigulevsky hydroelectric complex. Under conditions of high anthropogenic load ${ }^{12,13}$ and global warming,,$^{14,15}$ the relevance of such studies increases.

\section{Materials and methods}

Hydrochemical observations were carried out monthly in the period 2001-2018 on the river Volga in the area of the Zhigulevsky hydroelectric complex. ${ }^{16-18}$ Almost the entire water flow of the Volga River passes through this section. Zhigulevsky hydroelectric complex is the outlet section of the Kuibyshev reservoir. The entrance sections for it along the Volga branch are the Cheboksary hydroelectric complex, and along the Kama branch - the Nizhnekamsk hydroelectric complex (Figure 1). The Saratov and Volgograd reservoirs are located downstream of the Zhigulevsky hydroelectric complex.

At the Kuibyshev reservoir, seasonal regulation of water flow is carried out by the operating organization - the branch of JSC «RusHydro»-《Zhigulevskaya HPP» in accordance with the "Basic Rules for the Use of Water Resources of the Kuibyshev Reservoir on the Volga", approved by the order of the Ministry of Land Reclamation and Water Management of the RSFSR dated November 11, 1983 No. 596.

The total volume of the Kuibyshev reservoir is $57.3 \mathrm{~km}^{3}$, and the useful volume is $30.7 \mathrm{~km}^{3}$. The average long-term water runoff is $244 \mathrm{~km}^{3}$, the maximum is $366 \mathrm{~km}^{3}$, and the minimum is $148 \mathrm{~km}^{3} .{ }^{19,20}$ The useful volume allows for seasonal, weekly and daily regulation of water flow in the interests of various water users.

The hydrochemical observation point is located on the left bank of the Saratov reservoir, $2.5 \mathrm{~km}$ downstream of the Zhigulevsky hydroelectric complex. The structure of the hydroelectric complex includes: a hydroelectric power station, combined with bottom spillways; concrete spillway dam; two-stage gateway. The width of the reservoir at the observation point is $1.0 \mathrm{~km}$, and the depth is $6 \mathrm{~m}$. 
Water samples were taken with a Molchanov GR-18 bathometer in accordance with the regulatory requirements (GOST R 51592-2000). Water samples were filtered through a $0.45 \mu \mathrm{m}$ membrane filter. The determination of the mass concentration of chloride ions $\left(\mathrm{Cl}^{-}\right)$was carried out in accordance with the guidelines of Roshydromet (Table $1)$.

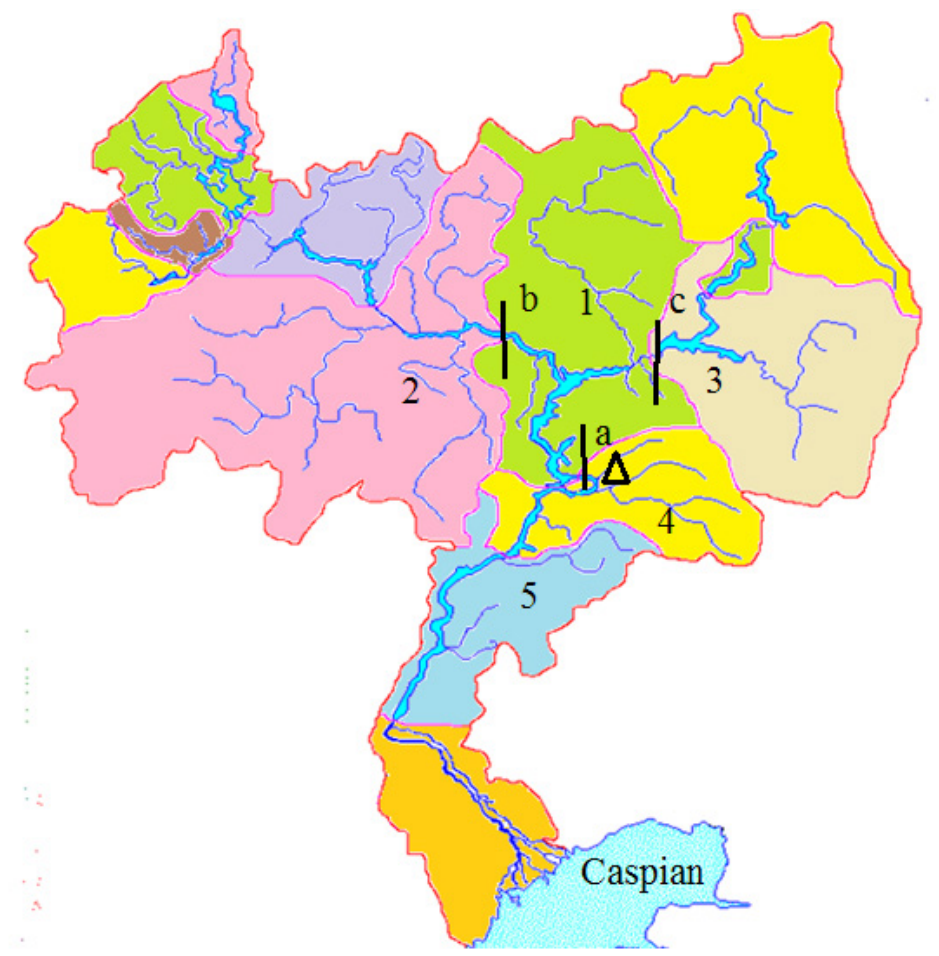

Figure I Location of the observation point $(\Delta)$ in the catchment area of the Volga River.

Reservoir basins: Kuibyshevsky ( I), Cheboksary (2), Nizhnekamsky (3), Saratov (4), Volgogradsky (5).

Gates of hydrosystems: a - Zhigulevsky, b - Cheboksary, c - Nizhnekamsky.

Table I Range and accuracy of measurement of the mass concentration of chloride ions ( $\left.\mathrm{CL}^{-}\right)$

\begin{tabular}{|c|c|c|}
\hline Analysis method & $\begin{array}{l}\text { Range measurements of the mass } \\
\text { concentration of chlorides }(X), \mathrm{mg} / \mathrm{dm}^{3}\end{array}$ & $\begin{array}{l}\text { Accuracy index (error limits at } \\
\text { probability } \mathbf{P}=0.95) \pm \Delta, \mathrm{mg} / \mathrm{dm}^{3}\end{array}$ \\
\hline RD 52.24.407-95 & from 10 to 250 & $1.4+0.030 \times$ \\
\hline RD 52.24.407-2006 & from 10 to 250 & $1.4+0.030 \times$ \\
\hline RD 52.24.407- 2017 & from 10 to 1000 & $1.4+0.030 \times$ \\
\hline
\end{tabular}

\section{Results and discussion}

The peculiarity of the hydrochemical regime of the Volga River is that it is a large river that flows from north to south at a distance of more than 3.5 thousand $\mathrm{km}$ and crosses several geographic zones. Therefore, the chemical composition of the waters of the Volga River does not correspond to the chemical composition of the waters of the side tributaries. At present, the Volga River is a complex natural and technical water system, where the regulation of water flow influences the formation of the hydrochemical regime of reservoirs. At the same time, the main regulator of the Volga river water flow is the Kuibyshev reservoir.

The concentration of chlorides in the water of the Kuibyshev reservoir is formed mainly under the influence of reservoirs located upstream. The influence of lateral tributaries (Sviyaga, Vyatka, Cheremshan), located in the local drainage area of the Kuibyshev reservoir, on the chloride content in the water is insignificant, since the volumes of water supplied from them are insignificant.
For the period 2001-2018 the average annual concentration of chlorides in the section of the Zhigulevsky hydroelectric complex was $27 \pm 2.2 \mathrm{mg} / \mathrm{dm}^{3}$, the highest $-31 \pm 2.3 \mathrm{mg} / \mathrm{dm}^{3}$, and the lowest $24 \pm 2.1 \mathrm{mg} / \mathrm{dm}^{3}$. Interannual changes in chloride concentration and water discharge are interrelated. For the same period, the average annual water consumption was 7.7 thousand $\mathrm{m}^{3} / \mathrm{s}$, the highest -9.0 thousand $\mathrm{m}^{3} / \mathrm{s}$, and the lowest -6.2 thousand $\mathrm{m}^{3} / \mathrm{s}$. 2004, 2005, 2007 and 2013 should be attributed to high-water years, and 2006, 2010, 2011 and 2015 to low-water years. In low-water years, the concentration of chlorides increased, and in high-water years, it decreased (Figure 2).

Seasonal changes in water discharge were much larger than interannual fluctuations. Average monthly water discharge $(\mathrm{Q})$ varied quite significantly from 5.3 to 18.3 thousand $\mathrm{m}^{3} / \mathrm{s}$ (Table 2). The highest average monthly water discharge $\left(\mathrm{Q}_{\max }\right)$ ranged from 6.5 to 26.1 thousand $\mathrm{m}^{3} / \mathrm{s}$, and the lowest $\left(\mathrm{Q}_{\min }\right)$ - from 4.1 to 11.1 thousand $\mathrm{m}^{3} / \mathrm{s}$. 


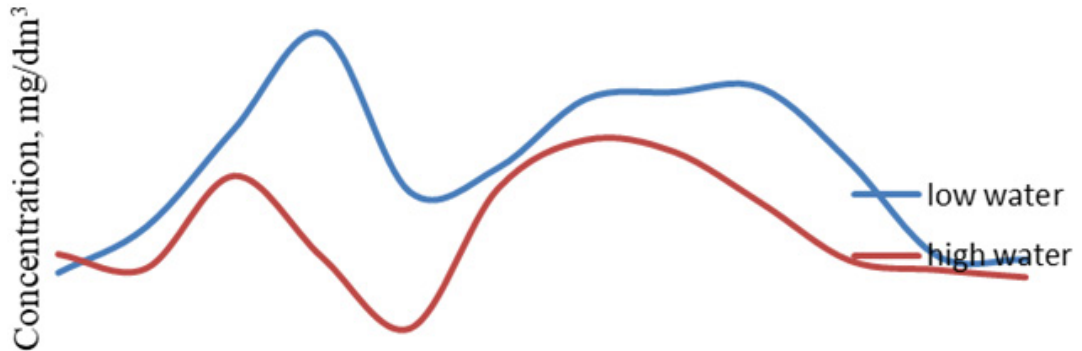

Month

Figure 2 Influence of water content on chloride concentration.

Table 2 Seasonal distribution of water flow rates

\begin{tabular}{|c|c|c|c|c|c|c|c|c|c|c|c|c|}
\hline \multirow{2}{*}{ Water discharge (thousand $\mathrm{m}^{3} / \mathrm{s}$ ) } & \multicolumn{12}{|c|}{ Month } \\
\hline & I & 2 & 3 & 4 & 5 & 6 & 7 & 8 & 9 & 10 & II & 12 \\
\hline $\mathrm{Q}$ & 5.9 & 6.2 & 5.9 & 11.8 & 18.3 & 8.7 & 6.5 & 5.8 & 5.6 & 5.3 & 6.2 & 6.3 \\
\hline Qmax & 7.4 & 9 & 8.7 & 18.6 & 26.1 & 13.8 & 14.1 & 8.1 & 6.6 & 6.5 & 12.4 & 8.8 \\
\hline Qmin & 4.5 & 4.9 & 4.2 & 5.1 & II.I & 5 & 4.8 & 2.1 & 4.4 & 4.2 & 4.1 & 4.5 \\
\hline
\end{tabular}

It is customary to distinguish three hydrological seasons: winter low water (December-March), spring flood (April-June) and summerautumn low water (July-November). The shortest is the period of spring flood, when the greatest amplitude of fluctuations in water discharge was observed (8.7-18.3thousand $\mathrm{m}^{3} / \mathrm{s}$ ). At the beginning of the spring flood in April, an increase in water discharge was observed, in May there was a peak of high water, and in June - a decline in spring flood and a decrease in water discharge to minimum values during the spring flood. Steady water discharge was observed during the winter low-water period and amounted to 5.9-6.3thousand $\mathrm{m}^{3} / \mathrm{s}$. The period of summer-autumn low-water period is the longest when water discharge is stable (5.3-6.5thousand $\left.\mathrm{m}^{3} / \mathrm{s}\right)$.

Seasonally, the average monthly concentration of chlorides $\left(\mathrm{Cl}^{-}\right)$ ranged from $22.8 \pm 2.1$ to $30.6 \pm 2.3 \mathrm{mg} / \mathrm{dm}^{3}$ (Table 3 ). The maximum chloride concentrations $\left(\mathrm{Cl}^{-}\right)_{\max }$ varied from $26.9 \pm 2.2$ to $41.3 \pm 2.6 \mathrm{mg}$ / $\mathrm{dm}^{3}$, the minimum $\left(\mathrm{Cl}^{-}\right)_{\min }$ - from $14.0 \pm 1.8$ to $24.0 \pm 2.1 \mathrm{mg} / \mathrm{dm}^{3}$ (Figure 3).

Table 3 Seasonal changes in chloride concentration

\begin{tabular}{|c|c|c|c|c|c|c|c|c|c|c|c|c|}
\hline \multirow{2}{*}{ Chlorides $\left(\mathrm{mg} / \mathrm{dm}^{3}\right)$} & \multicolumn{12}{|c|}{ Month } \\
\hline & I & 2 & 3 & 4 & 5 & 6 & 7 & 8 & 9 & 10 & II & 12 \\
\hline $\mathrm{Cl}-$ & 24.1 & 26.4 & 28.8 & 30.6 & 24.5 & 28.7 & 30.2 & 29.9 & 28.3 & 25.8 & 24.3 & 22.8 \\
\hline$(\mathrm{Cl}-)_{\max }$ & 27.9 & 39.1 & 35.6 & 41.3 & 34.1 & 41 & 39.3 & 35 & 36.7 & 29.8 & 29.3 & 26.9 \\
\hline$(\mathrm{Cl}-) \min$ & 20 & 21.7 & 20.4 & 22 & 14 & 19.3 & 21.8 & 24 & 22.9 & 21.8 & 20.8 & 18.6 \\
\hline
\end{tabular}

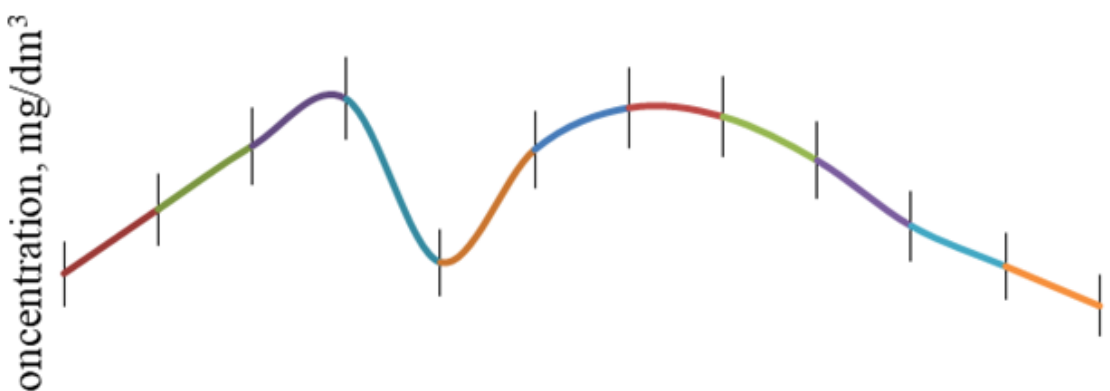

\section{Month}

Figure 3 Seasonal changes in chloride concentration $(\mathrm{Cl}-)(\tau, \perp-$ vertical error bars).

The chloride content in the outlet section of the Kuibyshev reservoir (section of the Zhigulevsky hydroelectric complex) is significantly influenced by the mixing of the Volga and Kama waters, which differ in chloride content. The concentration of chlorides in the water of 
the Kama River is 3-4 times higher than that of the Volga River. The waters of the Kama River and the Volga River mix with each other to varying degrees, depending on the water flow rate in the section of the Cheboksary and Nizhnekamsk hydroelectric complexes. The greatest influence of mixing of the Volga and Kama waters on the chloride content in the section of the Zhigulevsky hydroelectric complex is observed during the spring flood.

The chloride content in the outlet section of the Kuibyshev reservoir (section of the Zhigulevsky hydroelectric complex) is significantly influenced by the mixing of the Volga and Kama waters, which differ in chloride content. The concentration of chlorides in the water of the Kama River is 3-4 times higher than that of the Volga River. The waters of the Kama River and the Volga River mix with each other to varying degrees, depending on the water flow rate in the section of the Cheboksary and Nizhnekamsk hydroelectric complexes. The greatest influence of mixing of the Volga and Kama waters on the chloride content in the section of the Zhigulevsky hydroelectric complex is observed during the spring flood.

Seasonal variability of chloride concentration is due to the change of different water masses, as a result of the interaction of surface and underground components of water flow. During the spring flood, the role of melt waters with a low chloride content in the formation of water runoff increases, and the concentration of chlorides in the Volga water decreases. During the low-water period, the role of underground runoff gradually increases, and the concentration of chlorides increases until the beginning of the spring flood. Within a specific year, the amplitude of fluctuations depended on the volume of spring floods. The greater the flood volume, the greater the amplitude of seasonal fluctuations in the concentration of chlorides in water.

\section{Conclusion}

For the period 2001-2018 the average annual concentration of chlorides in the Volga River in the alignment of the Zhigulevsky hydroelectric complex was $27 \pm 2.2 \mathrm{mg} / \mathrm{dm}^{3}$, the highest $-31 \pm 2.3 \mathrm{mg} /$ $\mathrm{dm}^{3}$, and the lowest $-24 \pm 2.1 \mathrm{mg} / \mathrm{dm}^{3}$. The content of chlorides in the outlet section of the Kuibyshev reservoir is due to the interaction of the Volga and Kama waters. Small interannual fluctuations in chlorides are caused by changes in the water content of the Volga River. The concentration of chlorides increases in dry years, and decreases in wet years.

In the seasonal context, the average monthly concentration of chlorides $\left(\mathrm{Cl}^{-}\right)$ranged from $22.8 \pm 2.1$ to $30.6 \pm 2.3 \mathrm{mg} / \mathrm{dm}^{3}$. The maximum chloride concentrations $\left(\mathrm{Cl}^{-}\right)$max varied from $26.9 \pm 2.2$ to $41.3 \pm 2.6 \mathrm{mg} / \mathrm{dm}^{3}$, the minimum $\left(\mathrm{Cl}^{-}\right)$min - from $14.0 \pm 1.8$ to $24.0 \pm 2.1 \mathrm{mg} / \mathrm{dm}^{3}$. Intra-annual changes in chloride concentration are due to the interaction of surface and ground waters throughout the year. With the dominant role of groundwater in low-water periods, the concentration of chlorides in the Kuibyshev reservoir increases, and with the dominance of surface water (melt and rain), it decreases.

\section{Acknowledgments}

The authors are grateful to the staff of the hydrology department of the Zhigulevskaya HPP branch of PJSC RusHydro for the information provided on the flow rates of the Volga River in the alignment of the Zhigulevsky hydroelectric complex.

\section{Funding}

None.

\section{Conflicts of interest}

The authors declare that there is no conflict of interest.

\section{References}

1. Surface water quality in the Russian Federation. Yearbook 2019 (Rostovon-Don: GKhI); 2020. 578 p.

2. Alekin OA. Fundamentals of hydrochemistry. L.: Gidrometoizdat; 1970. 444 p.

3. Nikanorov AM. Hydrochemistry. St. Petersburg: Gidrometeoizdat; 2001. $447 \mathrm{p}$.

4. Zenin AA, Belousova NV. Hydrochemical dictionary. 1988. 240 p.

5. Zenin AA. Hydrochemistry of the Volga and its reservoirs. 1965. 260 p.

6. Debolsky VK, Grigorieva IL, Komissarov AB. Changes in the chemical composition of water in the Volga from source to mouth in the summer low-water season in 2009. Environmental protection and nature management. 2011;3:68-73.

7. Debolsky VK, Grigorieva IL, Komissarov AB, et al. Modern hydrochemical characteristics of the Volga River and its reservoirs. Water: chemistry and ecology. 2010;11:2-12.

8. Shashulovskaya EA, Mosiyash SA, Orlov AA, et al. Long-term changes in water quality in the Lower Volga areas, differing in hydrological regime. Bulletin of the Samara Scientific Center of the Russian Academy of Sciences. 2016;5(2):382-386.

9. Torgashkova ON, Volovik NS. Comprehensive assessment of the degree of pollution of the water environment of the Volga River Izvestiya Saratov University. New ser. Ser Chemistry Biology Ecology. 2011:96-102.

10. Nikanorov AM, Bryzgalo VA, Kosmenko LS. The role of the river inflow of dissolved chemicals in the anthropogenic transformation of the state of the aquatic environment in the mouth area of the Volga river. Water: chemistry and ecology. 2010:6-12.

11. Selezneva AV. From monitoring to regulation of anthropogenic load on water bodies. Samara: SamNTs RAN; 2007. 107 p.

12. Waters of Russia (state, use, protection) 1995. Yekaterinburg: RosNIIVKh; 1996. 103 p.

13. State report "On the state and use of water resources of the Russian Federation in 2018". Moscow: NIA - Priroda; 2019. 290 p.

14. Bespalova KV, Seleznev VA, Selezneva AV. Water quality of the Volga reservoirs in the context of global climate warming Resource conservation and ecological development of territories. Collection of articles Samara. pp 2017:126-129.

15. Ovchinnikova SI, Shirokaya TA, Pashkina OI. Main trends in changes in the hydrochemical parameters of the aquatic ecosystem of the Kola Bay (2000-2011). Vestnik MGTU. 2012;3:544-550.

16. Selezneva AV, Bespalova KV, Seleznev VA. Assessment of seasonal variability of water quality in a surface source of drinking water supply. Urban planning and architecture. 2018;2(31):20-26.

17. Seleznev VA, Bespalova KV, Selezneva AV. Seasonal variability of phosphate content in the Volga water under conditions of anthropogenic eutrophication of reservoirs. Journal of Water Chemistry and Technology. 2018;5:307-311.

18. Bespalova KV, Selezneva AV, Seleznev VA. Seasonal variability of the concentration of mineral phosphorus in the water of the Saratov reservoir In the book: The Volga and its life. Collection of abstracts of the AllRussian conference. $2018.8 \mathrm{p}$.

19. Hydrometeorological regime of lakes and reservoirs of the USSR: Kuibyshev and Saratov reservoirs. 1978. 269 p.

20. GS Rosenberg. Kuibyshev reservoir (scientific information reference book). Togliatti: IEVB RAS; 2008. 123 p. 